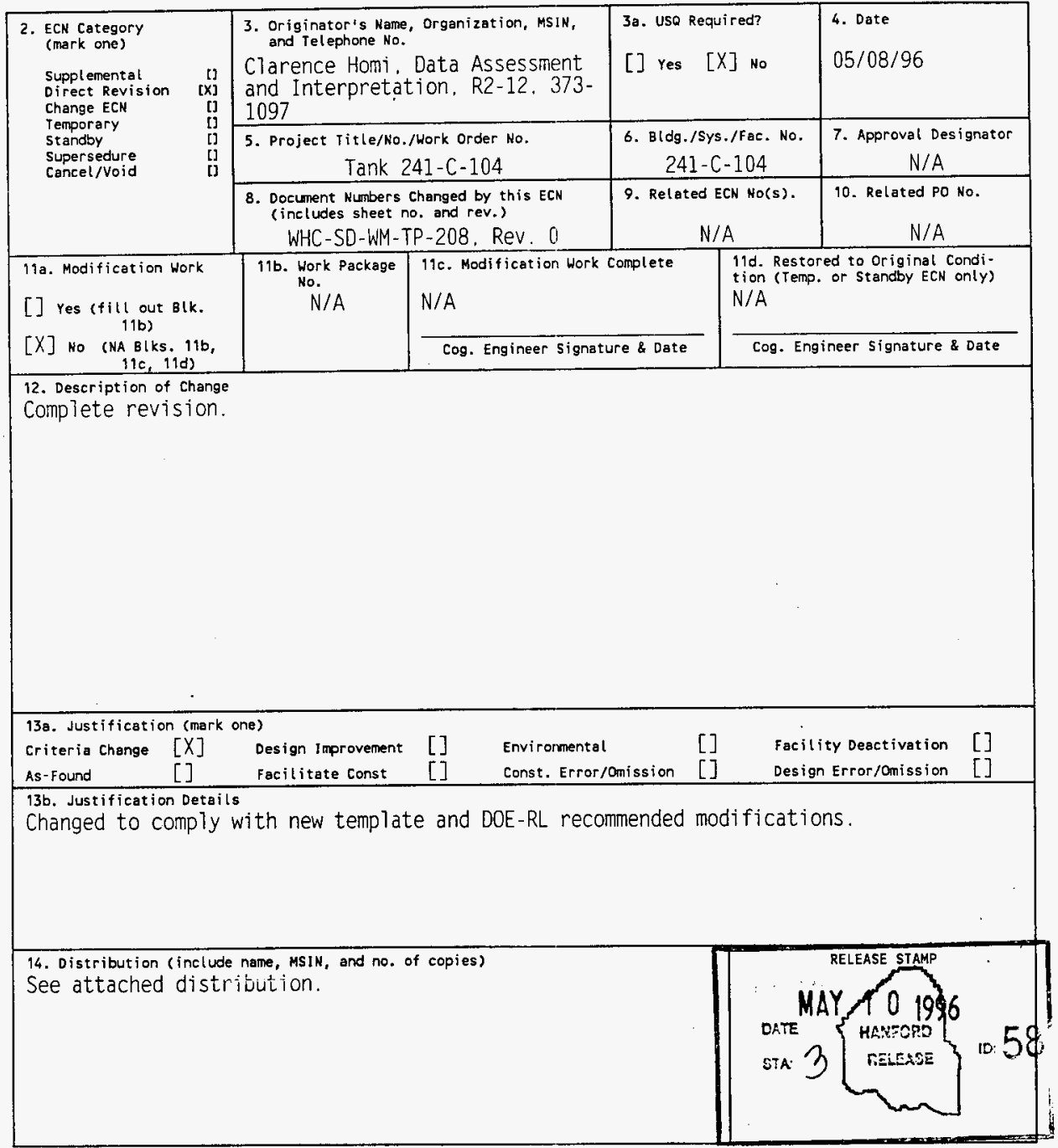




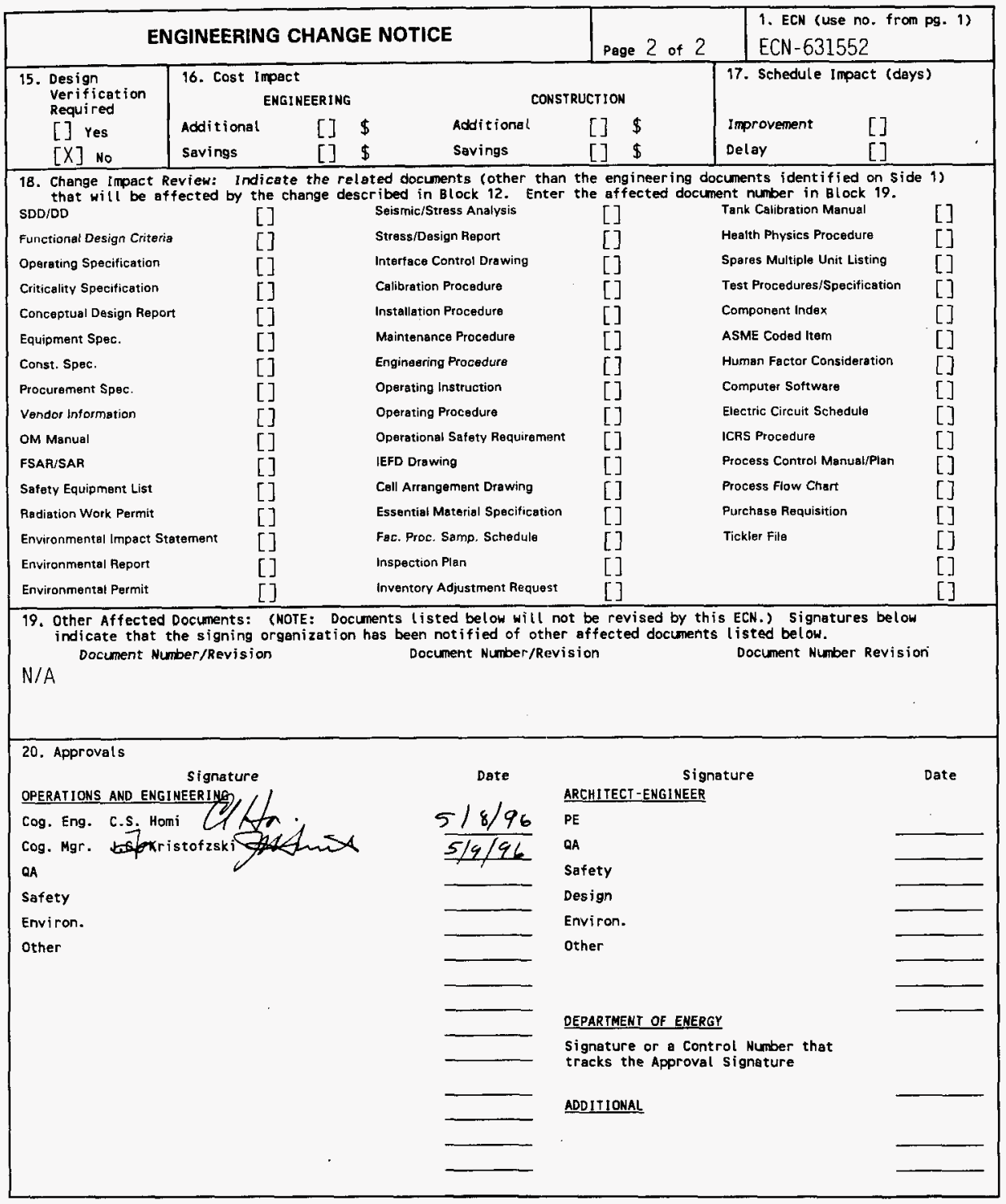




\section{Tank 241-C-104 Tank Characterization Plan}

C. S. Homi

Westinghouse Hanford Company, Richland. WA 99352

U.S. Department of Energy Contract DE-AC06-87RL10930

$\begin{array}{lll}\text { EDT/ECN: } & \text { ECN-631552 } & \text { UC: } 2070 \\ \text { Org Code: } & 79200 & \text { Charge Code: N4G6A } \\ \text { B\&R Code: } & \text { EW } 3120074 & \text { Total Pages: }\end{array}$

Key Words: Characterization. General Safety Issues, Specific Safety Issues. Information Requirements. Schedule

Abstract: This document is a plan that identifies the information needed to address relevant issues concerning short-term and long-term storage and long-term management of single-shell tank 24l-C-104.

TRADEMARK DISCLAIMER. Reference herein to any specific commercial product, process, or service by trade name, trademark, manufacturer, or otherwise, does not necessarily constitute or imply its endorsement, recommendation, or favoring by the United States Goverment or any agency thereof or its contractors or subcontractors.

Printed in the United States of America. To obtain copies of this document, contact: WHC/BCS Document Control Services, P.0. Box 1970, Mailstop H6-08, Richland WA 99352, Phone (509) 372-2420; Fax (509) $376-4989$
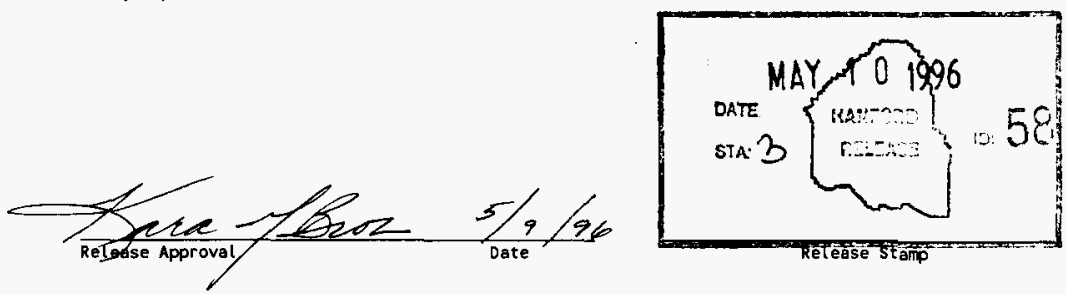

Approved for Public Release 


\section{RECORD OF REVISION}

(2) Title

Tank 241-C-104 Tank Characterization Plan

CHAMGE CONTROL RECORD

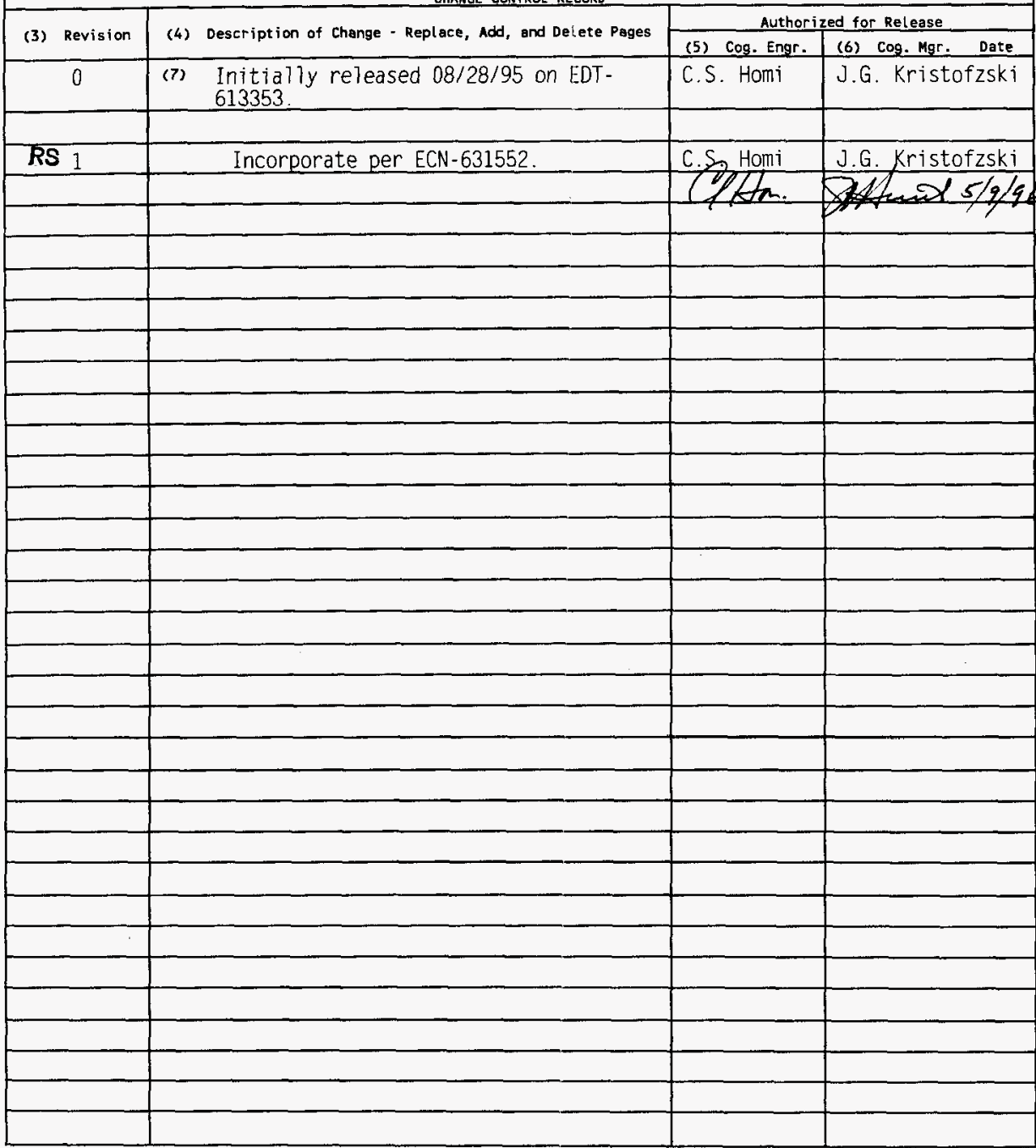




\title{
Tank 241-C-104 Tank Characterization Plan
}

\author{
C. S. Homi
}

Westinghouse Hanford Company

Date Published

May 1996

Prepared for the U.S. Department of Energy

Office of Environmental Restoration and

Waste Management

\section{(20) Westinghouse P.0. Box 1970 Hanford Company Richlan, wastingen}

Management and Operations Contractor for the

U.S. Department of Energy under Contract DE-AC06-87RL10930 


\section{WHC-SD-WM-TP-208 REV 1}

\section{TABLE OF CONTENTS}

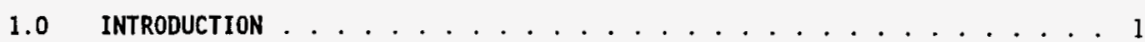

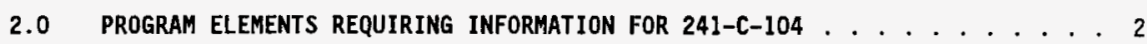

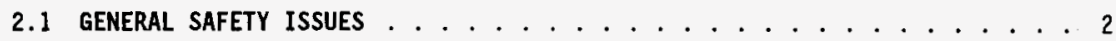

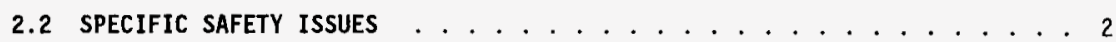

2.2 .1 Ferrocyanide ................. 2

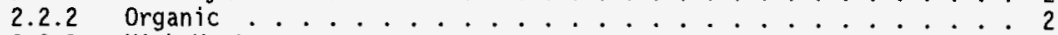

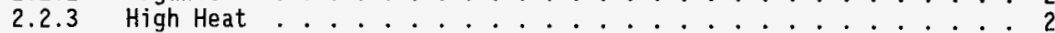

2.2 .4 Flammable Gas . . . . . . . . . . . . . . . 2

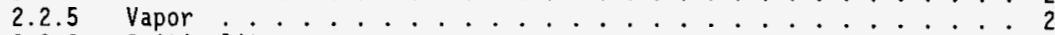

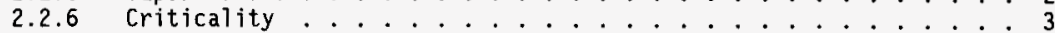

2.3 CONTINUING OPERATIONS . . . . . . . . . . . . . . . 3

2.2.1 Compatibility/Stabilization ............. 3

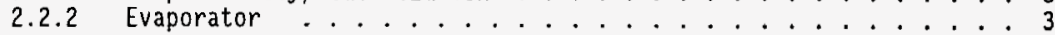

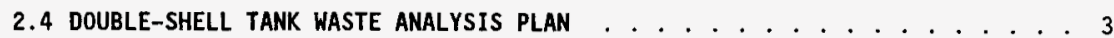

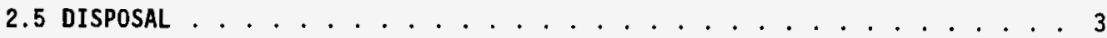

2.5 .1 Retrieval ............... 3

2.5.2 Pretreatment/vitrification $\ldots \ldots \ldots$

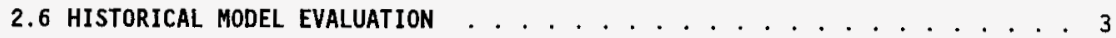

3.0 HOW INFORMATION WILL BE OBTAINED ................ 4

4.0 PRIORITY OF INFORMATION REQUIREMENTS .................. . . . 4

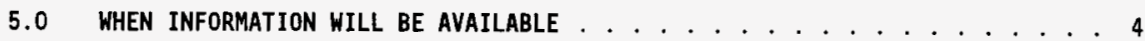

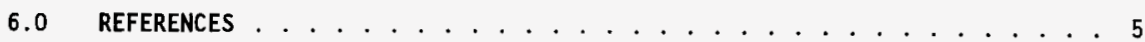

\section{LIST OF TABLES}

Table 4-1: Integrated DQO Requirements and Priorities........... 4 


\section{WHC-SD-WM-TP-208 REV 1}

\subsection{INTRODUCTION}

This Tank Characterization Plan (TCP) identifies the information needed to address relevant issues concerning short-term and long-term safe storage and long-term management of single-shell tank 241-C-104 (C-104). It should be understood that the various needs and issues surrounding tank $C-104$ are evolving as new information about the tank is uncovered. As a result of this progression, this TCP addresses only the issues that, to this date, have been identified. It is expected that deviations from this plan may occur as additional issues or needs arise which impact the management of tank $\mathrm{C}-104$. This TCP will be revised as necessary to reflect those changes or deviations. The plan reflects the best information available as of May 1996.

Tank C-104 was constructed between 1943 and 1944 and was put into service in October 1946. Initially tank C-104 received metal waste from the fourth quarter of 1946 until the fourth quarter of 1954. Tank $\mathrm{C}-104$ is the first tank in a three tank cascade which also includes 241-C-105 and 241-C-106. By February 1947 the cascade was ful1. The tank cascaded between 1946 and 1953. The metal waste was siuiced in the fourth quarter 1953 to recover uranium. The supernatant was sent to the 244-CR process vault in 1954 and the tank was declared empty in the first quarter of 1955. U plant waste was added to the tank in the fourth quarter of 1955. The tank was emptied again and received or contained coating waste from the first quarter of 1956 until the third quarter of 1969. From the first quarter of 1956 until the third quarter of 1972, the tank received Plutonium Uranium Extraction (PUREX) cladding waste. From the first quarter of 1969 until the third quarter of 1976, the tank received various wastes. The tank received decontamination waste from the second quarter of 1965 until the first quarter of 1974. From the fourth quarter of 1969 until the fourth quarter of 1972, the tank received PUREX organic wash waste. During the third and fourth quarters of 1970 , the tank received thorium high-level waste. From the fourth quarter of 1970 until the second quarter of 1976, the tank received PUREX low-level waste. The tank received PUREX high-level waste from the fourth quarter of 1973 until the second quarter of 1975. From the first quarter of 1974 until the fourth quarter of 1975, the tank received wastewater. From the second quarter of 1976 uritil the fourth quarter of 1977, the tank contained dilute PUREX feed. During 1978 the waste was classified as non-complexed. From the first quarter of 1979 until the fourth quarter of 1980, the waste was classified as complex waste. The tank is sound and was declared inactive in March 1980. Tank C-104 is actively ventilated, was partially isolated in December 1982 and declared interim stabilized in September 1989 with intrusion prevention completed in February 1991 (Brevick 1994).

Tank C-104 currently has a total waste volume of $1,117 \mathrm{~kL}$ (295 kgal), which is equivalent to $261 \mathrm{~cm}$ (102.7 inches) of waste as measured from the baseline of the tank (Hanlon 1996).

This tank is not on any watch List.

Near-term sampling and analysis activities are focused on either verifying or changing the Watch List tank status, and identifying any new safety issues. Should any safety issues be identified, additional analysis will occur consistent with the identified issue.

In addition to the resolution of the safety issues, it is intended that all tank waste will be subject to pretreatment and retrieval to prepare for final storage or disposal. Presently, these long-range plans have yet to be fully identified and are, therefore, not included in this document. 


\subsection{PROGRAM ELEMENTS REQUIRING INFORMATION FOR TANK 241-C-104}

This section identifies the various program elements, and identifies which of these programs require characterization data from tank C-104.

\subsection{GENERAL SAFETY ISSUES}

The Tank Safety Screening Data Quality Objective (Dukelow et al. 1995) describes the sampling and analytical requirements that are used to screen waste tanks for unidentified safety issues. Analytical requirements for the safety screening of a tank are energetics, total alpha activity, moisture content, density, and flammable gas concentration.

\subsection{SPECIFIC SAFETY ISSUES}

\subsubsection{Ferrocyanide}

This tank is not on the Ferrocyanide Watch List, therefore no information needs are currently identified for this program element.

\subsubsection{Organic}

This tank is not on the Organics Watch List, therefore no information needs are currentiy identified for this program element.

\subsubsection{High Heat}

This tank is not on the High Heat Watch List, therefore no information needs are currently identified for this program element.

\subsubsection{Flammable Gas}

This tank is not on the Flammable Gas watch List, therefore no information needs are currently identified for this program element.

\subsubsection{Vapor}

Al1 177 underground tanks must be vapor-sampled for organic solvent screening as per Recommendation 93-5 Implementation Plan (DOE-RL 1996). Some tanks may require additional vapor sampling due to other program needs. These tanks may be classified into four categories: (1) those tanks which are to be rotary mode core sampled (as a consequence of the rotary sampling system exhauster permit requirements); (2) tanks on the Organic or Ferrocyanide Watch Lists; (3) tanks in C farm; and (4) tank 24l-BX-104, due to vapor exposure. Information needs must satisfy Data Quality Objectives for Tank Hazardous Vapor Safety Screening (Osborne and Buckley 1995), and for rotary mode only, Rotary Core Vapor Sampling Data Quality Objective (Price 1994), and Data Quality Objective for Regulatory Requirements for Hazardous and Radioactive Air Emissions Sampling and Analysis (Mulkey and Markillie 1995) as amended by Status of the Current Understanding of the Toxic Air Pollutants (TAPS) and Hanford Tank Farm Vapor Space Characterization; Recommended Path Forward and Justification for Continued RMCS Exhauster Operations (Laws 1996).

Tank C-104 was vapor sampled in March 1994 in support of 0sborne et al. (1994). 


\section{WHC-SD-WM-TP-208 REV 1}

\subsubsection{Criticality}

No information separate from that for the general safety issue of tank C-104 are currently identified for this program element. However, if the general safety screening of tank $\mathrm{C}-104$ identifies a potential criticality concern, analyses for fissile materials and neutron absorbers and poisons will be performed as identified in the safety screening data quality objective (DQ0).

\subsection{CONTINUING OPERATIONS}

\subsubsection{Compatibility/Stabilization}

This section does not apply to tank C-104.

\subsubsection{Evaporator}

This section does not apply to tank C-104.

\subsection{DOUBLE-SHELL TANK WASTE ANALYSIS PLAN}

This section does not apply because tank $\mathrm{C}-104$ is a single shell tank.

\subsection{DISPOSAL}

\subsubsection{Retrieval}

Current retrieval needs (B1oom and Nguyen 1995) do not call for test samples to be taken from tank $\mathrm{C}-104$.

\subsubsection{Pretreatment/Vitrification}

Tank C-104 has been identified as a bounding tank for pretreatment/disposal process development strategy (Kupfer et al. 1995). The strategy only requires that sample material be made available via archive samples and does not require any specific analyses to be done on the samples.

\subsection{HISTORICAL MODEL EVALUATION}

Bounding tanks and data requirements for historical model evaluations are found in DQO Historical Model Evaluation Data Requirements (Simpson and McCain 1995). Tank C-104 has been identified as a primary bounding tank for checking waste variability. All single-shell tanks were prioritized in the Tank Waste Characterization Basis (Brown et al. 1995) document using the Historical DQO. 


\subsection{HOW INFORMATION WILL BE OBTAINED}

The number of samples required to characterize a tank is a function of waste heterogeneity and the desired confidence to make a correct decision. As directed by the safety screening $D Q 0$, if inadequate information exists to determine an appropriate number of samples, two vertical profiles will be obtained. These vertical profiles may be obtained using core, auger (for shallow tanks), or grab samples. If analysis of these profiles reveals that additional profiles are required to meet data needs, more sample profiles will be requested. Prior to rotary sampling it is necessary to vapor sample the tank as per requirements of Rotary Core Vapor Sampling Data Quality objective (Price 1994).

\subsection{PRIORITY OF INFORMATION REQUIREMENTS}

Vapor sampling was completed in March 1994. Rotary mode core sampling is scheduled to begin February 1997 (Stanton 1996). Refer to Table 4-1 for the current DQO requirements and planned sampling and analytical requirements.

Table 4-1: Integrated DQO Requirements and Priorities

\begin{tabular}{|l|l|l|l||}
\hline $\begin{array}{l}\text { Sampling } \\
\text { Event }\end{array}$ & \multicolumn{1}{|c|}{ Applicable Issues } & Sampling Requirements* & \multicolumn{1}{|c||}{$\begin{array}{c}\text { Analytical } \\
\text { Requirements }\end{array}$} \\
\hline $\begin{array}{l}\text { Vapor } \\
\text { Sampling }\end{array}$ & $\begin{array}{l}\text {-Organic Solvent Layer } \\
\text { 93-5 Vapor Issue } \\
\text {-Rotary Mode Sampling } \\
\text { Dq0s } \\
\text {-Hazardous Vapor DQ0 }\end{array}$ & $\begin{array}{l}\text { Steel canisters, } \\
\text { Triple Sorbent Traps, } \\
\text { Sorbent Trap Systems }\end{array}$ & $\begin{array}{l}\text { Flammable Gas } \\
\text { Organic Vapors } \\
\text { Permanent Gases }\end{array}$ \\
\hline $\begin{array}{l}\text { Rotary } \\
\text { Mode Core }\end{array}$ & $\begin{array}{l}\text {-Safety Screening DQ0 } \\
\text {-Historical DQO }\end{array}$ & $\begin{array}{l}\text { Core samples from a } \\
\text { minimum of 2 risers } \\
\text { separated radially to } \\
\text { the maximum extent } \\
\text { possible. } \\
\text { Combustible gas } \\
\text { measurement. }\end{array}$ & $\begin{array}{l}\text { Flammability, } \\
\text { Energetics, Moisture, } \\
\text { Total alpha activity, } \\
\text { Density, Anions, } \\
\text { Metals, Radionuclides, } \\
\text { Total Organic Carbon }\end{array}$ \\
\hline
\end{tabular}

* Consult each applicable DQ0 in force at the time for sampling and analytical requirements.

\subsection{WHEN INFORMATION WILL BE AVAILABLE}

According to Stanton (1996) data are expected to be available from the rotary mode core sampling event for tank C-104 in July 1997. This time may be altered if the sampling schedule changes. Data are available from the March 1994 vapor sampling. 


\section{WHC-SD-WM-TP-208 REV 1}

\subsection{REFERENCES}

Bloom, G. R., and Q. H. Nguyen, 1995, Characterization Data Needs for Development, Design and Operation of Retrieval Equipment Developed Through the Data Quality Objective Process, WHC-SD-WM-DQ0-008, Rev. 0, Westinghouse Hanford Company, Richland, Washington.

Brevick, C. H., 1994, Supporting Document for the Historical Tank Content Estimate for $C$ Tank Farm, WHC-SD-WM-ER-313, Rev. 0, ICF Kaiser Hanford Company, Richland, Washington.

Brown, T. M., S. J. Eberlein, and T. J. Kunthara, 1995, Tank Waste Characterization Basis, 1995, WHC-SD-WM-TA-164, Rev 1, Westinghouse Hanford Company, Richland, Washington.

DOE-RL, 1996, Recommendation 93-5 Implementation Plan, DOE/RL-94-0001, Rev. 1, U.S. Department of Energy, Richland, Washington.

Dukelow, G. T., J. W. Hunt, H. Babad, and J. E. Meacham, 1995, Tank Safety Screening Data Quality Objective, WHC-SD-WM-SP-004, Rev 2, Westinghouse Hanford Company, Richland, Washington.

Hanlon, B.M., 1996, Waste Tank Summary for Month Ending January 31, 1996, WHC-EP-0182-94, Westinghouse Hanford Company, Richland, Washington.

Kupfer, M. J., W. W. Schultz, J. T. Slankas, 1995, Strategy for Sampling Hanford Site Tank Wastes for Development of Disposal Technology, WHC-SD-WM-TA-154, Rev. 1 , Westinghouse Hanford Company, Richland, Washington.

Laws, G. L., 1996, Status of the Current Understanding of the Toxic Air Pollutants (TAPS) and Hanford Tank Farm Vapor Space Characterization; Recommended Path Forward and Justification for Continued RMCS Exhauster Operations, (telephone conference memorandum, 01830-96-022, to Distribution, March 8) Westinghouse Hanford Company, Richland, Washington

Mulkey, C. H. K. D. Markillie, 1995, Data Quality Objective for Regulatory Requirements for Hazardous And Radioactive Air Emissions Sampling and Analysis, WHCSD-WM-DQ0-021, Rev. 0, Westinghouse Hanford Company, Richland, Washington

0sborne, J. W., L. L. Buckiey, 1995, Data Quality Objectives for Tank Hazardous Vapor Safety Screening, WHC-SD-WM-DQO-002, Rev. 2, Westinghouse Hanford, Richland, Washington.

Osborne, J. W., J. L. Huckaby, E. R. Hewitt, C. M. Anderson, D. D. Mahlum, B. A. Pulsipher, and J. Y. Young, 1994, Data Quality Objectives for Generic In-Tank Health and Safety Vapor Issue Resolution, WHC-SD-WM-DQO-002, Rev. 0, Westinghouse Hanford, Richland, Washington.

Price, D. N. 1994, Rotary Core Vapor Sampling Data Quality Objective, WHC-SD-WM-SP-003, Rev. 0, Westinghouse Hanford Company, Richland, Washington.

Simpson, B. C., D. J. McCain, 1995, Historical Model Evaluation Data Requirements, WHC-SD-WM-DQ0-018, Rev. 0, Westinghouse Hanford Company, Richland, Washington. 


\section{WHC-SD-WH-TP-208 REV 1}

Stanton, G. A., 1996, Baseline Sampling Schedu7e, Change 96-02, (internal memo 75610-96-06, to Distribution, April 17), Westinghouse Hanford Company, Richland, washington. 


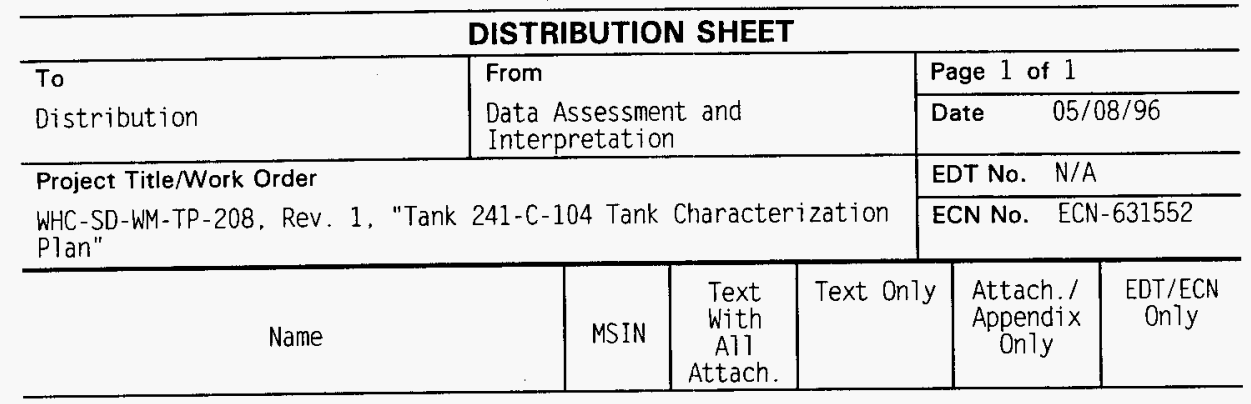

ONSITE

U. S. Department of Energy -

Richland Field office

W. Liou

N. W. Willis

Westinghouse Hanford Company

G. D. Forehand

C. S. Homi

Central Files

T.C.R.C.

$\begin{array}{ll}57-54 & x \\ 57-54 & x\end{array}$

$\begin{array}{ll}\text { S7 }-21 & X \\ \text { R2 }-12 & x \\ \text { A3 }-88 & x \\ \text { R2 }-12 & X\end{array}$

\section{OFFSITE}

U. S. Department of Enerqy - Headquarters

office of Environmental Restoration and

Waste Management EM-563

12800 Middlebrook Road

Germantown. MD 20874

J. A. Poppiti 